\title{
Europeanization or Party Politics? Explaining Government Choice for Corporatist Concertation
}

\section{ALEXANDRE AFONSO* and YANNIS PAPADOPOULOS**}

This article assesses whether changes in government choice for policy concertation with trade unions and employers are better explained by international or domestic factors. We compare patterns of corporatist governance in a strongly Europeanized policy domain (labor migration policy) and in a weakly Europeanized policy domain (welfare state reforms) over the last 20 years in Austria and Switzerland. We show that there is no systematic difference in patterns of concertation between the two policy sectors and that factors linked to party politics play a bigger role in the choice of governments for concertation. If the base of party support for policies is divided, governments are more prone to resort to corporatist concertation as a way to build compromises for potentially controversial or unpopular policies. By contrast, ideologically cohesive majority coalitions are less prone to resort to concertation because they do not need to build compromises outside their base of party support.

\section{Introduction}

Corporatist policy concertation has played a central role in welfare and labor market adjustment in most countries in Western Europe. Far from being in irremediable decline as predicted earlier, this process whereby governments negotiate policy reforms with trade unions and employers has persisted in most countries traditionally considered as corporatist, and has even emerged in countries where unilateral policymaking by governments used to be the norm. Recent research shows, for instance, that while $50 \%$ of European governments were willing to pursue concerted welfare reforms in 1980, this share had reached $80 \%$ in 2000 (Baccaro and Simoni 2008, 1327). Between 1980 and 2006, there were 157 attempts to negotiate so-called social pacts between governments, employers, and trade unions over wage, welfare, or labor market reforms (Hamann and Kelly 2010, 1).

In many ways, the persistence of corporatist concertation as a privileged way of policymaking is puzzling when set against the main assumptions of the earlier neo-corporatist literature of the 1970s and

*Max Planck Institute for the Study of Societies

${ }^{* *}$ University of Lausanne

Governance: An International Journal of Policy, Administration, and Institutions, Vol. $\bullet \bullet$, No. $\bullet \bullet$, •• 2012 (pp. ••-・・).

(C) 2012 Wiley Periodicals, Inc.

doi:10.1111/j.1468-0491.2012.01582.x 
1980s (see, e.g., Lehmbruch and Schmitter 1982). The bargains that typically underpinned neo-corporatism in the past-for instance, expansionary fiscal policies or welfare expansion in exchange for wage moderation-have become ever more difficult to pursue in a context of permanent budgetary austerity, internationalized markets, and steady decline in trade union membership (Avdagic 2010, 629). In order to explain why governments still do-and sometimes do not-negotiate policy reforms with organized interests in this new context, recent analyses have focused on two main sets of factors, namely, European integration and changing patterns of party politics.

On the one hand, concertation has been understood as a domestic response to the process of European integration and its incentives for domestic coordination. Schmitter and Grote $(1997,3)$ write, for instance, that the rebirth of corporatism in Europe in the 1990s was primarily due to "the feverish efforts of national governments to adapt to EU directives, product and professional standards, verdicts of the ECJ and the convergence criteria for EMU." Along a similar line, Schmidt (2006) argues that European integration has opened up the policymaking process of its member states to organized interests and that corporatist systems of policymaking are more adapted to the requirements of European integration than statist systems where the state alone makes policy. On the other hand, a more recent strand of research has largely explained concertation by domestic factors related to changing patterns of party politics (Anthonsen and Lindvall 2009; Baccaro and Simoni 2008; Hamann and Kelly 2010). Within this framework, concertation has been understood as a way for weak governments to build political support within parliament or to carry out unpopular reforms in a context where they cannot rely upon a stable core of support among voters.

In this article, we confront the "Europeanization" hypothesis with the domestic "party politics" rival hypothesis to explain variation in the choice of governments to seek agreements with trade unions and employers over policy reforms. To do so, we compare patterns of corporatist concertation in a strongly Europeanized policy sector (immigration policy) and in a weakly Europeanized policy sector (welfare reform) in Austria and Switzerland over the last 20 years. In this manner, we aim to provide a finegrained analysis of the political logics that underpin policy concertation. The article is organized as follows. The next section describes the main dependent variable, corporatist policy concertation, and its variation. The following section presents hypotheses on the impact of Europeanization on policy concertation, and then on the impact of domestic party politics. The empirical section presents comparative case studies on the two policy domains under scrutiny in Austria and Switzerland. The conclusion assesses the explanatory power of "domestic" and "international" factors, and argues that domestic party politics plays a bigger role in the incidence of corporatist concertation, even if Europeanization can influence party politics. 


\section{Corporatist Concertation as Government Choice}

Corporatist concertation can be defined as a governance pattern in which governments "share their policymaking prerogatives with trade unions and employer associations, not just informally by incorporating their inputs but also formally by setting up a bargaining table and engaging in negotiations with them over public policy" (Baccaro and Simoni 2008, 1323). In this article, we are therefore interested in the procedural rather than the structural dimension of corporatism as a dependent variable, or corporatism as a policymaking procedure (concertation) rather than a structure of organized interests. Hence, what we seek to explain is the choice of governments to involve organized interests in policy reforms in a given policy sector rather than the overall degree of corporatism in a national political system, or the success or failure of policy agreements. Besides, we are interested in sectoral patterns of concertation, often conducted (at least in part) behind closed doors, rather than in the formalized and publicly announced multi-issue agreements analyzed by the literature on social pacts (Avdagic, Rhodes, and Visser 2011; Hamann and Kelly 2010).

Recent research has shown that the structural and procedural dimensions of corporatism may no longer be as closely coupled as assumed in the past (Baccaro 2003, 2009). Whereas corporatist structures, such as encompassing and centralized labor organizations, have been considerably weakened in most countries of Western Europe, corporatist procedures of policymaking have largely persisted, and have even emerged in countries such as Italy or Ireland, which did not display what were thought to be the prerequisites of corporatism (Baccaro 2003). In this context, what is particularly puzzling is the persisting will of governments to seek agreements with trade unions and employers over labor market and welfare reforms despite these fundamental changes in structure. Following Baccaro and Simoni $(2008,1324)$, we consider governments as the pivotal actors in this process since they have exclusive control over access to decision making. As the sole holders of a democratic mandate to make binding decisions, governments can opt for strategies of policymaking allowing for the participation of organized interests, or alternatively for strategies where organized interests are excluded, with a significant degree of variation in between.

Whereas earlier analyses of social pacts essentially understood concertation as a strategy of macroeconomic management (Fajertag and Pochet 2000; Hancke and Rhodes 2005), we consider it to be a process in which governments strategically pursue political-and not only economicgoals (Ahlquist 2010; Avdagic 2010; Baccaro and Simoni 2008; Hamann and Kelly 2010). In this framework, it is generally acknowledged that a situation of political weakness is a determining factor in the choice of governments to negotiate and "share public space" with organized interests (Crouch 1986). Hence, "when the state shares public space, it usually 
lacks the legitimacy, competencies, and implementation capacity to singlehandedly carry out desired reforms of social and employment policy" (Ebbinghaus 2010, 256). Weakness does not only mean that governments are dependent on trade unions and employers in the steering of the macroeconomy, but also that they may be dependent on them to build and maintain political support within parliament or among voters. More precisely, as policy, office, and vote seekers, governments engage in negotiations with organized interests when they believe that the benefits of concertation in terms of legitimization outweigh their costs: Concertation implies compromises and therefore moving away from the ideal policies of ruling parties; it can be lengthy, and the failure to come up with agreements can cause a loss of credibility for all actors involved (Hamann and Kelly 2010, 24). It is in this context that we investigate how Europeanization and different configurations of party politics affect the willingness of governments to engage in corporatist concertation.

In order to assess the extent of participation of organized interests in policymaking, we use a simple typology inspired by those developed by Falkner and Leiber (2004) and Talos and Kittel (2001). In line with the idea that government autonomy plays a central role in the resort to concertation, policymaking processes can be characterized by the degree of autonomy of the government vis-à-vis organized interests in the decisionmaking process (Falkner and Leiber 2004). Hence, (1) unilateral decision making refers to a policymaking process where the autonomy of governments is maximal: Organized interests are not consulted, and policy is made exclusively by the government. (2) Consultation refers to a policymaking process where the government consults organized interests, although without engaging in negotiations with them, and remains the sole actor in control of policy outputs. In (3) tripartite concertation, the government sets up a bargaining table where public officials, employers, and trade unions negotiate policy reforms. However, they do not necessarily need to find an agreement that is fully backed by participating actors; the government remains free to carry out policy reforms even without the full support of social partners. Finally, a (4) corporatist compromise - what Talos and Kittel refer to as Akkordierung - comes about when trade unions, employers, and government negotiate a policy reform and eventually reach an agreement that is fully supported by participating actors. If the difference between concertation and corporatist compromise may be due to persisting conflict between trade unions and employers, it remains a choice of the government to carry out a reform even if one or both social partners do not support concertation, or to not carry out a reform until an agreement supported by both sides is reached. Hence, we assume that there is still a great deal of leeway for governments to build corporatist compromises if they really desire so. In general, both employers and trade unions may prefer reaching compromises over policy reforms in order to shape their outcomes rather than unilateral reforms carried out by the government. The Wassenaar agreement of 1982 in the 
Netherlands is a good example where the "shadow of hierarchy" played a decisive role in shaping a corporatist compromise (Visser and Hemerijck 1997). Drawing upon these basic assumptions, it is now possible to discuss the two competing explanations of policy concertation outlined above.

\section{Europeanization and Corporatist Concertation}

The domestic impact of European integration-Europeanization-has been considered important for policy concertation because it "has affected not only the traditional ways in which state actors formulate and implement policy but also the traditional routes by which societal actors gain access and exercise influence in policy-making" (Schmidt 2006, 670). Even if Europeanization has been defined in a variety of ways (see, e.g., Radaelli 2003), for the purpose of this analysis, we adopt a rather restrictive definition where Europeanization is defined as the extent to which national governments share authority with EU supranational bodies in a given policy domain (Hooghe and Marks 2001). That is, a strongly Europeanized domain is an institutional decision-making environment where national autonomy in decision making is strongly constrained by EU rules, whereas a weakly Europeanized policy domain is a domain where national autonomy in decision making remains substantial. In the following section, we outline two mechanisms whereby Europeanization can impact on the choice of governments to opt for concertation, either negatively or positively.

\section{Europeanization as Weakening of Domestic Corporatist Concertation}

Europeanization entails a redistribution of power resources among domestic actors (Risse and Börzel 2003, 63). Moravcsik (1994) notably argues that European integration "strengthens the state" domestically to the detriment of other domestic actors, such as parliaments and organized interests. Since governments generally enjoy a monopoly of representation of national interests in supranational decision-making arenas, they can "cut slack" vis-à-vis domestic political constraints by removing issues from the domestic sphere (Grande 1996; Moravcsik 1994). By playing with different levels of decision making (two-level games), they can increase their autonomy and loosen the pressure of domestic interest groups, who only enjoy limited access to intergovernmental arenas. Governments can then come back to the domestic level and present European policies as imposed by more powerful countries, thereby shifting the blame to other actors. Hence, the distribution of power in "Europeanized" policy arenas is considered different from strictly "domestic" settings. In this perspective, Europeanization reduces national autonomy in decision making but increases the autonomy of governments at the domestic level ("paradox of weakness") (Grande 1996), which in turn tends to reduce the incentives to negotiate policies with domestic organized interests. 
Considering that concertation draws upon a balance of power between state and society (Crouch 1986), European integration is likely to undermine it by altering this balance to the advantage of the former. Besides, the pace of decision making in Europeanized policies tends to be quicker, which also reduces the room for domestic concertation. The loss of power of organized interests may be counterbalanced by corporatist deals struck at the supranational level between Euro-federations of interest groups, but this does not compensate for the loss of influence at the domestic level (Falkner and Leiber 2004, 247).

Hypothesis 1: There is a weaker degree of concertation in strongly Europeanized policy domains than in weakly Europeanized policy domains.

\section{Europeanization as Strengthening of Domestic Concertation}

Taking an opposite stance, more recent research has argued that Europeanization has had a strengthening, or at least stabilizing, effect on domestic corporatist concertation. Contradicting former predictions regarding a general demise of corporatism after the Single European Act, the emergence of social pacts in many European countries, like Ireland, Spain, or Italy, in the run-up to the Economic and Monetary Union (EMU), led many authors to consider European integration as an incentive for domestic concertation because of the "problem load" it imposed on national governments (Schmitter and Grote 1997). In relation to the idea of government autonomy outlined above, the underlying idea is that Europeanization tends to weaken governments at the domestic level, for instance, because EU policies may be considered less legitimate and enjoy weaker political support (Schmitter 2003,79-80). If governments are weakened, this may act as an incentive for concertation in order to build political support.

Schmidt (2006) recently argues that European integration weakens state centrality at the domestic level and fosters the opening up of domestic policymaking to the participation of private organized interests. Corporatist systems of policymaking, where the state negotiates policy with organized interests, are believed to be better adapted to EU policymaking than statist systems where governments make decisions unilaterally. The underlying mechanism here is a process of "institutional isomorphism" between EU policy processes, characterized by a strong degree of openness to social interests in policy formulation, and the domestic level. Research on the implementation of EU social policy directives gives empirical support for such a view. In their analysis of the implementation of EU social directives within member states, Falkner and Leiber (2004) show a slightly "stabilizing" effect of EU social directives on domestic corporatism whereby the EU model is held up as a "best practice."

Hypothesis 2: There is a stronger or at least a similar degree of concertation in Europeanized policy domains than in domestic policy domains. 


\section{Party Politics and Corporatist Concertation}

A growing body of literature seeking to explain variation in corporatist concertation has emphasized the role of changes in party politics (Anthonsen and Lindvall 2009; Baccaro and Simoni 2008; Hamann and Kelly 2010). Whereas earlier analyses of corporatism during the Keynesian consensus had pointed to the incumbency of social democratic parties in government as a precondition for corporatist policymaking, this element seems to have lost its pertinence with the loosening of ties between unions and social-democratic parties (Hamann and Kelly 2010, 33; Traxler, Blaschke, and Kittel 2001, 302). In this context, recent scholarship has turned to other partisan factors to explain corporatist policymaking in times of "permanent austerity." In many ways, the logic underpinning these analyses reassess the interdependencies between party governments and corporatist arenas as two alternative instances of consensus building (Lehmbruch 1977, 98ff).

In their analysis of corporatist policymaking in four countries, Anthonsen and Lindvall $(2009,169)$ argue that the persistence of corporatist policymaking within consociational democracies has come to depend on diverging dynamics of party competition. Corporatist policymaking has tended to persist in countries where executive power has remained characterized by grand coalitions, transient or mixed government coalitions, whereas it has tended to decline in countries where the left-right cleavage has come to dominate and where parties have progressively sought to form ideologically cohesive left- or right-wing governments. Baccaro and Simoni $(2008,1342)$ argue for their part that "governments are willing to share their policymaking prerogatives with the social actors when they are politically weak, either because they lack strong and united parliamentary majorities or because they are otherwise marred by internal struggles and legitimacy crises. In these circumstances, associating trade unions to policy formation can be expedient for governments, as it allows them to activate supplementary channels of consensus mobilization." Hence, concertation is not assumed to follow long-term trends but rather to be mobilized by governments when they find themselves in specific political circumstances. We adopt this perspective and show that there is in fact substantial variation across issues and depending on parties in power.

In many ways, both arguments are consistent with the idea that weak government autonomy fosters corporatist concertation as argued above, even if weak autonomy can take different forms. Both minority governments and grand coalitions can be considered weakly autonomous, although for different reasons, whereas ideologically cohesive majority coalitions, especially right-wing coalitions, display a higher degree of autonomy. First, minority governments are weakly autonomous because they have to negotiate political support with other parties in parliament, and they have been found to be more prone to negotiate social pacts 
(Avdagic 2010, 21). In this article, however, we do not test this assumption and focus on party configurations whose causal impact on concertation has been less explored. Second, grand coalitions can also suffer from low autonomy in a different way, namely because they are faced with specific coordination problems. According to veto player theory, large coalition governments have a lower action capacity because, by definition, they have to accommodate heterogeneous policy preferences, particularly if the coalition partners are marred by internal divisions, notably because of significant ideological differences among them (Tsebelis 1999, 591). In this context, governments can use trade unions and employers as "policy brokers" between parties with ideologically broad differences, as a way to build compromises when parties cannot agree among themselves (Heinisch 2000, 90). Trade unions and employers may be more prone to compromises than parties because they are not subjected to the centrifugal tendencies observed in multiparty systems (Sartori 1976, 131-145). Third, and by contrast, ideologically cohesive majority coalitions are characterized by a greater degree of autonomy and may therefore be less prone to engage in tripartite negotiations because they do not need to build support outside. Besides, their smaller internal ideological differences constitute a minor impediment on action. This is especially the case for right-wing coalitions that may not count upon the support of the trade union clientele, contrarily to left-wing governments.

Hypothesis 3: Grand coalitions with heterogeneous preferences are more prone to concertation than ideologically cohesive right-wing majority coalitions.

\section{Cases and Methods}

In the empirical section of this article, we compare governance patterns across strongly and weakly Europeanized policy sectors in Austria and Switzerland over the last 20 years. A common methodological problem emphasized by many scholars in the analysis of the domestic impact of Europe is the lack of variance in the independent variable, so that it is difficult to assess if the EU is really a cause of variation in the phenomena that are observed (Haverland 2006; Levi-Faur 2004). Here, we use case selection to provide a variance regarding Europeanization. If similar outcomes can be observed with and without Europeanization, then its causal impact can be substantially downplayed. This is done by comparing decision-making processes across policy areas and, whenever possible, across time as well (before and after Europeanization). Given the type of data collection associated with the fluid and often secretive nature of sectoral corporatist concertation, we use a comparative qualitative casestudy analysis that provides a higher degree of conceptual validity (George and Bennett 2005, 19).

Austria and Switzerland are interesting cases to test the impact of Europeanization and party politics on corporatist policymaking for two 
main reasons. First, corporatist concertation has traditionally played a central role in social and economic policymaking in both countries, even if it has been underpinned by different power relationships between labor and capital: strong employers in Switzerland, strong labor in Austria (Katzenstein 1984). In Austria, the influence of organized interests is sustained by quasi-public, compulsory organizational structures (Chambers) with a right of consultation in policymaking (Pelinka 2008). In Switzerland, organized interests are major veto players in policymaking mainly because they can challenge decisions in a popular referendum, which acts as a strong incentive for governments to include them in policymaking (Neidhart 1970). While the great degree of institutionalization of corporatist arrangements in both countries has entailed a great deal of stability in corporatist arrangements, there is nevertheless substantial variation in the choice of governments to opt for concertation across policy issues and across time. Hence, our dependent variable is not completely determined by the institutional context. In many ways, if our hypotheses on variation in government choice are confirmed in these countries where government choice is constrained by an institutional structure favoring corporatist resilience, they may well apply in contexts where corporatism is less institutionalized.

Second, both are consociational democracies that have undergone similar changes in party competition in recent years, so that cases provide variance across time when it comes to the role of party politics (see Table 1). In Austria, this happened with the weakening of the two major parties ÖVP (Osterreichische Volkspartei, conservative) and SPÖ (Sozialdemokratische Partei Österreich, social-democrat) to the advantage of the radical-populist FPÖ (Freiheitspartei Österreich, radical right) punctuated by its accession to power in a coalition with the ÖVP between 2000 and 2006, which adopted a very hostile stance toward social partnership (Obinger and Talos 2006). In Switzerland, changes took place over the 1990s with the important increase in the parliamentary strength of the national-populist SVP (Schweizerische Volkspartei, radical right), whose share of seats in the lower chamber increased from 13\% in 1991 to $31 \%$ in 2007 , becoming the largest parliamentary faction. One could argue of course that both countries differ in terms of EU membership. Austria has been a member of the EU since 1995, whereas Switzerland has remained outside the EU, even if this country has established a set of bilateral agreements with the EU-notably on the free movement of workers-which allows for the analysis of "Europeanized" policies there as well (Fischer, Nicolet, and Sciarini 2002). However, we do not make hypotheses based on differences between the two countries regarding EU membership, because Switzerland cannot really be considered a true "control case" for the impact of EU membership (Haverland 2006, $140)$.

In each country, differences in the extent of concertation are expected across issues (Europeanization hypotheses) and across party coalitions 


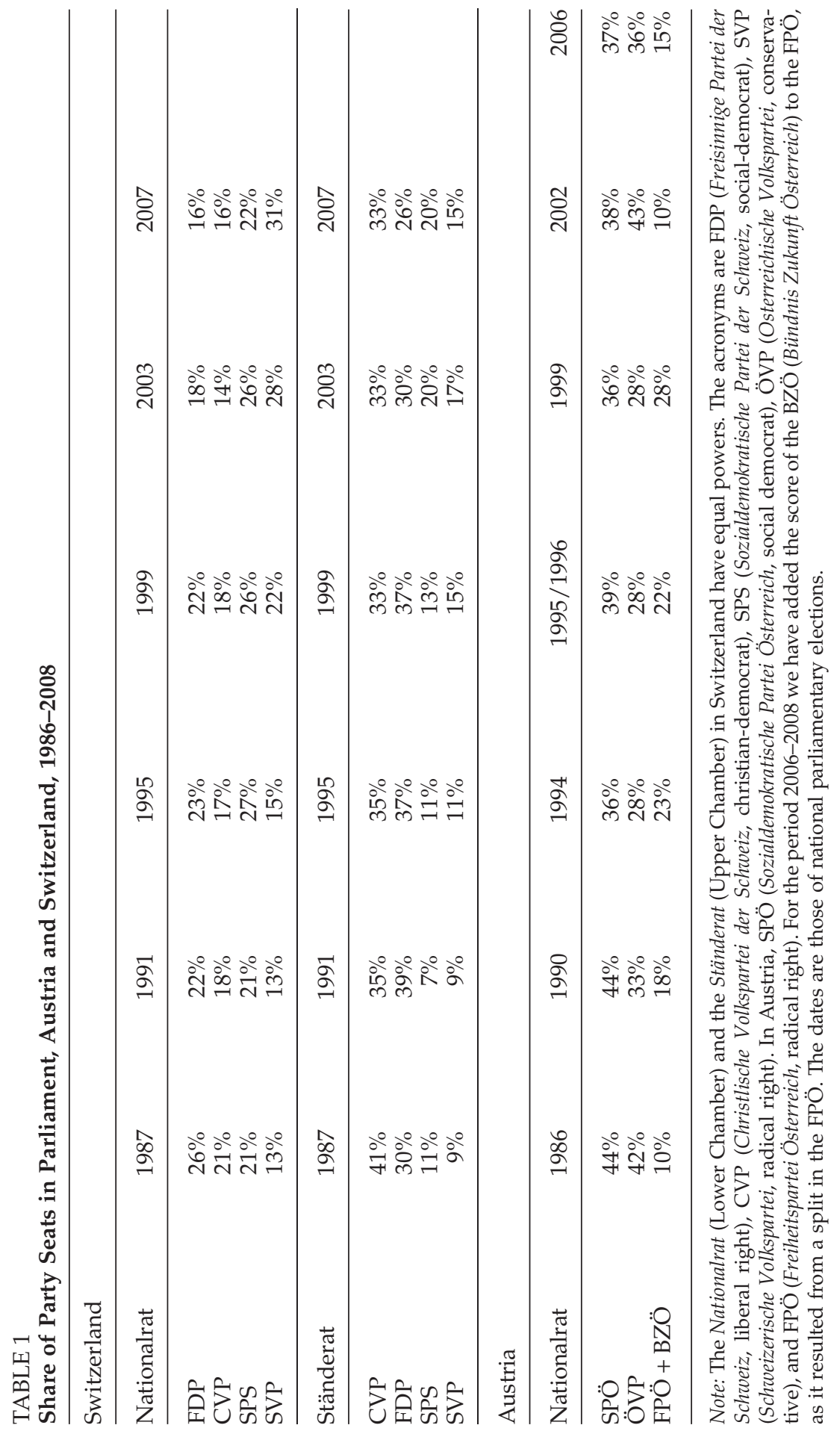


(party politics hypothesis). Even if Switzerland has been uninterruptedly ruled by a grand coalition composed of the same parties (liberals, christian democrats, social democrats, Swiss People's Party) since 1959, its specific institutional structure where the government is not dependent on the confidence of parliament-similar to a presidential system-and low party discipline allow for a great deal of variation in party coalitions across issues-similar to what is observed in the U.S. Congress. Hence, in the Swiss case, it is not variation in the party composition of governments that matters for concertation but the legislative coalitions over specific issues.

In both countries, we analyze intra-EU labor migration policy as an example of a strongly Europeanized policy domain where most decisions are taken at the EU level (Hooghe and Marks 2001). We analyze dominant modes of policymaking from the 1980s to 2008, with a particular focus on the patterns of policymaking underpinning the opening of the Austrian and Swiss labor markets for workers of new EU member states that joined in 2004. Welfare reforms are analyzed as a weakly Europeanized case because EU pressures have been less important and less direct than in the free movement of workers. European initiatives in this domain, notably through the Open Method of Coordination and the broad framework of the European Employment Strategy, remain weakly constraining for member states (Höpner and Schäfer 2008, 13) and specifically do not apply to Switzerland. Data were gathered through extensive document and press analysis, as well as 21 in-depth interviews with key actors (trade union officials, employer representatives, members of parliament (MPs), and ministry officials). ${ }^{1}$

\section{Austria: When Party Politics Offsets Europeanization}

Corporatist concertation has played a central role in policymaking in Austrian politics since the Second World War. The main social partners-the Chamber of Labour, the ÖGB (Österreichischer Gewerkschaftsbund) trade union on the one hand and the Economic Chamber on the other-traditionally agreed on policies before the parliamentary process began. Corporatist compromises were then turned into legislation by virtue of the strong coordination channels between organized interests and the two major parties ÖVP and SPÖ (Talos and Kittel 2001). This was the case for both immigration policy and social policymaking. For both cases, however, fairly abrupt changes took place when a new right-wing coalition between the conservative ÖVP and the radicalpopulist FPÖ with a clear antitrade union agenda came to power in 2000, after 30 years of the uninterrupted presence of the Social Democrats in government (Obinger and Talos 2006). As we show, governance patterns are rather uniform across strongly and weakly Europeanized domains, but vary significantly across ruling party coalitions. 


\section{Labor Migration Policy}

Labor migration policy in Austria has traditionally been closely managed within corporatist institutions (Talos and Kittel 2001, 142-146). The first guest-worker programs in the 1960s provided, for instance, for the entry of a contingent of guest workers (requested by employers) in exchange for an expansion of the competences of the ÖGB trade union in the commission for prices and wages (requested by labor) (Bauböck and Perchinig 2006, 7). The immigration law of 1975 further institutionalized the powers of the social partners in immigration policy at all levels, giving competences to parity committees from the setup of immigration quotas to individual work permits. The rationale for this policy was essentially protectionist, and trade unions in particular were eager to keep control over the supply of foreign labor (Bauböck and Wimmer 1988). These strongly institutionalized patterns of social partnership in this policy field remained stable until the 1990s, when Austria joined the EU in 1995 under the grand SPÖ-ÖVP coalition (1986-2000). Fearing a loss of their power after EU accession, both social partners were given extensive guarantees as to their core competences in policymaking, notably to ensure their support in the referendum vote to join the EU (Falkner 2000, 237-238). An agreement between SPÖ and ÖVP promised that the long-standing practice of social partner participation in the shaping of Austrian social and economic policies would be upheld even during EU membership. This would apply during the period of progressive Europeanization of labor migration policy under the grand coalition, most notably when it came to EU enlargement.

Because of the geographical proximity of Austria vis-à-vis accession countries, the free movement of workers and potential threats of wage dumping have been a constant concern for Austrian trade unions and employers even before the start of the accession process (Interview 2). As early as 1996, trade unions demanded that the issue of free movement of workers be put at the center of any future negotiation on EU enlargement, more precisely through the use of appropriate transitional periods and criteria regarding the convergence of eastern economies with EU 15 standards. In this phase (1996-2000), there was a close involvement of organized interests in the elaboration of the Austrian position on enlargement, notably with the ministry of foreign affairs (Interview 4; Tumpel 2004). Interestingly, the closure of the labor market was also favored by employers. Business interests in Austria are dominated by small- and medium-sized enterprises (SMEs), who would have liked an increase in cheap foreign labor but were afraid of competition from self-employed workers or from foreign companies possibly posting workers from new EU member states (Heschl 2008; Interviews 2, 7). In this respect, the agreement on transitional measures in the Treaty of Accession whereby a flexible transitional period could be adopted by member states, was considered to be a victory for Austrian social partners during the 
enlargement negotiations (Interview 4). In this first phase, a corporatist compromise prevailed.

Things changed substantially when the right-wing coalition ÖVP/FPÖ came to power in 2000 and found itself in charge of the domestic application of the transitional arrangements agreed upon by the previous grand coalition (the so-called EU-Erweiterungs-Anpassungsgesetz) (Osterreichisches Parlament 2004). The domestic legislative framework providing for the implementation of limitations in labor migration from the new member states was adopted just before EU enlargement took effect, with a very swift decision-making process including only the minimal compulsory consultation of social partners (Interview 9). Even if it was underpinned by a consensus between employers and trade unions upon the closure of the Austrian labor market, specific dispositions introduced by the right-wing government provided for bypassing quotas, as well as restrictions on access to unemployment benefits. These were met by criticism from trade unions in the formal consultation process (Bundesarbeitskammer Österreich 2004) and even led the social democrats to vote against the law in parliament (Stenographisches Protokoll 2004, 59). Both social partners and parliament were put under pressure for a quick ratification process, the ruling coalition arguing that the labor market could not be protected if a law was not adopted before enlargement took effect (Stenographisches Protokoll 2004, 60). In the following period, loopholes in the legislation allowed domestic employers to bypass limitations, so that the corporatist control that prevailed over the supply of foreign labor (corporatist compromise) faded to a large extent (EIRO 2004; Interview 9).

In many ways, this evolution is in line with existing research describing the collapse of social partnership during the FPÖ/ÖVP right-wing coalition (Obinger and Talos 2006). However, it stands in contrast with analyses of the impact of Europeanization on Austrian social partnership in the area of EU social policy, which emphasized the stabilizing effect of the EU on social partner involvement that otherwise was crumbling (Falkner and Leiber 2004, 260). Supporting our argument, other empirical evidence on the involvement of social partners in the implementation of EU national action plans for employment points to a marginalization of trade unions during the ÖVP/FPÖ right-wing coalition in Europeanized policies (EIRO 2003). In this domain, differences in corporatist policymaking were more due to party political factors than to European integration: Both corporatist compromises and unilateral policymaking could be observed when Europeanization was present. Patterns of concertation changed when party coalitions in power changed as well.

\section{Welfare State Reforms}

Social policymaking has been the core of corporatist arrangements in Austria. All the major phases of expansion of the welfare state have been mostly underpinned by corporatist compromise between the social 
partners and the two major parties (Obinger and Talos 2010, 105). The prevailing strongly corporatist mode of decision making was essentially similar to the one described for labor migration policy and was even more institutionalized. Social partners had tight control over both decision making and the implementation of pension and unemployment schemes according to the principle of self-administration (Selbstverwaltung) (Obinger and Talos 2010, 103). This did not mean that conflicts were totally absent, but in the period 1970-1986, corporatist compromises were the central feature of policymaking (Obinger and Talos 2010; Talos and Kittel 2001). Things began to change in the second half of the 1980s, as mounting debts and an economic slowdown gave way to a slight declining influence of corporatist compromises (Crepaz 1994). However, compromises were still sought in every major domain. Up to the 1990s, measures of retrenchment carried out to balance budgets were compensated by measures of expansion as part of encompassing package deals. Even if the context was one of austerity, corporatist policymaking still played a central role throughout the 1990s. Over this period, social partners have been said to act as "modernization brokers" set against the weakening of the two major parties to the advantage of the ever-growing Freedom party FPÖ (Heinisch 2000).

In this context, the real breakdown in corporatist policymaking took place when the ÖVP /FPÖ right-wing coalition came to office in 2000. ÖVP and FPÖ were united on a policy agenda guided by tax cuts and budgetary austerity. The institutionalized role of trade unions in social policymaking was systematically bypassed by the new government, so that trade unions were confronted with a series of decisions made unilaterally by the government (Obinger and Talos 2010, 113). Trade union representatives were taken out of a series of social insurance institutions. Social policy competences were systematically taken away from the social affairs ministry to the more pro-market Ministry of Economics and Employment. Employment policy was shifted from social policy to "competitiveness" policy (Der Standard 2000). This responded to both the traditionally hostile stance of the FPÖ toward trade unions and a change of strategy within the ÖVP, whose new reform agenda could only be pushed through against trade unions and social democrats, and not in a coalition government with them. Legislation was increasingly introduced directly in Parliament as a way to bypass the obligation to consult social partners on government proposals (Obinger and Talos 2006, 10; Pelinka 2008, 439). An example of such methods of policymaking is the pension reform carried out in 2003, which abolished a series of early retirement benefits besides a series of other retrenchment measures, and was met by the biggest protest actions by trade unions since the Second World War. This unilateral stance was somewhat tempered down when the FPÖ was considerably weakened after anticipated elections in 2006, but social partnership was nevertheless widely considered to have become a hollow shell during that period (Interviews 3, 5). 
The 2006 elections and the restoration of a grand coalition SPÖ-ÖVP led to a "revival" of social partnership. The grand coalition appeared as a pragmatic alliance between two weakened major parties despite their growing ideological differences, which eventually led to its collapse and the organization of anticipated elections in 2008 (Interview 3; Obinger 2008). Interestingly, in this polarized context, social partners came up with a whole series of corporatist compromises that they could then present as ready-made solutions to ruling parties for whom agreeing on policies had become very difficult (Interviews 3, 5; Der Standard 2009). It was also a way to keep control over policy initiatives and avoid the marginalization of the period 2000-2006, particularly for trade unions. Trade unions and employers had maintained closer cooperation patterns than political parties that had grown apart from each other. Hence, Europeanization does not seem to have an independent impact since the patterns of change in modes of governance are basically similar in both strong and weak Europeanized domains. Party political factors by contrast were the leading triggers of change in corporatist policymaking.

\section{Switzerland: When Party Politics Mediates Europeanization}

Even if patterns of corporatist policymaking have not been as institutionalized in Switzerland as in Austria, organized interests have nevertheless played a central role in the policymaking process. Traditionally, strong interest organizations, especially on the side of business, have trumped weak political parties in the drafting of economic and social legislation (Kriesi and Trechsel 2008). In recent years, however, the strong increase in the parliamentary representation of the radical-populist, eurosceptic Swiss People's Party (SVP) at the expense of center-right parties has entailed a reconfiguration of policy alliances across issues, with substantial consequences for corporatist concertation.

\section{Labor Migration Policy}

Labor migration policymaking in Switzerland from the 1960s onward was characterized by close networks of influence between public authorities and employers on the one hand, and the relative marginalization of trade unions on the other (Cattacin 1987, 61). This system was not as corporatist as in Austria because of the absence of formal structures of interest intermediation, and the asymmetry of power between labor and capital. Similar to Austria, Switzerland was running guest-worker programs-on an even wider scale-but trade unions did not exert much control over their definition. This system underwent a process of gradual transformation over the 1990s (Fischer, Nicolet, and Sciarini 2002), notably through an increased preference for EU workers, but the core patterns of governance were preserved. The real change would come with the opening of the 
Swiss labor market for EU workers, which would interestingly strengthen corporatist governance due to a specific configuration of party politics.

During the 1990s, the Swiss government negotiated an agreement with the EU on the free movement of workers, which provided for the opening of the Swiss labor market to EU workers (Fischer, Nicolet, and Sciarini 2002). The issue of free movement of workers was indisputably the most debated because of persisting differentials in wages and unemployment rates between Switzerland and neighboring countries, the size of the immigrant population (about $25 \%$ of the workforce), and continuous popular concern about this issue. Since the agreement on free movement was part of a broader set of agreements considered of vital importance for export industries, the government was eager to have it ratified domestically. However, in a context where the SVP had a different stance from center-right parties over relationships with the EU, this proved to be difficult. Three distinct party blocs emerged; none of them could gather a parliamentary majority on its own. The radical-right SVP was opposed to any sort of opening of the Swiss labor market for EU workers, whereas center-right parties favored closer economic integration with the EU in a bilateral manner. Social democrats and trade unions were in principle in favor of labor market opening but demanded guarantees for the protection of wage and social standards. Trade unions made it clear that they were ready to oppose the bilateral agreements as a whole in a popular referendum if measures of labor market protection were not put in place (Interview 16). In this context, it was necessary to build a broader base of political support. Even if there is a grand coalition in Switzerland, the low degree of parliamentary discipline creates a situation close to that of a minority government when right-wing parties disagree. On the one hand, social democrats would support the agreement only if guarantees were given to trade unions in terms of labor market protection, and the support of trade unions was crucial in the eventuality of a popular vote. If the government wanted the bilateral agreements to come about, it had to rally trade unions and social democrats through compensations on labor market protection (Interviews 15, 16).

After a hard-fought concertation procedure between trade unions and employers, a compromise was achieved by coupling labor market opening with a set of so-called domestic "accompanying measures" aimed at preventing risks of wage dumping: a lightening of formal requirements for the extension of collective labor agreements, a new law on posted workers, and the establishment of tripartite committees in charge of the monitoring of labor market developments in each canton (Fischer, Nicolet, and Sciarini 2002). When it came to extending free movement to new EU member states after EU enlargement, this strategy was once again used by trade unions to achieve side payments for their support of European integration despite the reluctance of employers and public authorities (Interviews 11, 14, 16). This time, they achieved a further loosening of formal requirements for the extension of collective labor agreements, 
thereby securing their power in collective bargaining, as well as a reinforcement in the staffing of the labor inspectorate (Conseil Fédéral 2004a, $2004 b)$. The project was accepted by all major parties in parliament except the SVP, which supported the referendum launched against the agreement. The package was eventually accepted by a majority of Swiss voters in 2005. The pivotal role conferred on trade unions by the divisions among right-wing parties over European integration allowed them not only to be strongly involved in policymaking in a typical corporatist-compromise pattern, but also to further institutionalize corporatist structures in this domain and reinforce their strength in collective bargaining (Interviews 11,16). This reinforcement of corporatist governance in a strongly Europeanized domain is most interesting because, as we will show, the fate of corporatist policymaking in welfare state reforms has been characterized by a clearly different evolution.

\section{Welfare State Reforms}

Social policymaking in Switzerland has also been traditionally characterized by close cooperation patterns between government, trade unions, and employers. Corporatist compromises were the dominant mode of elaboration of social policies up to the 1990s. The possibility for organized interests to challenge any law passed in parliament in a popular referendum generally gave strong incentives for governments and organized interests to agree on policies in the early stages of the policy process (Neidhart 1970). The core social security schemes, such as unemployment insurance and pensions, even if they have been established relatively late, have been introduced mostly as compromises between government and social partners. This was notably the case of the unemployment insurance scheme introduced in the aftermath of the economic crisis of the mid1970s (Kriesi 1980). Up to the 1990s, Switzerland's good economic performance and stable political coalitions left corporatist governance patterns practically untouched. From the 1990s onward, however, the deterioration of public finances due to slow growth and higher unemployment has enhanced distributional conflicts, making corporatist compromises more difficult. When left-right compromises were found in the first half of the 1990s, it was between progressive segments of right-wing parties and social democrats around retrenchment measures coupled with measures of "recalibration," for instance, around issues of gender equality or activation whose financial consequences were rather limited. The pension or unemployment policy reforms analyzed by Häusermann, Mach, and Papadopoulos (2004) are good examples of such cross-class modernization alliances.

Toward the end of the 1990s, however, the strengthening of the SVP has strongly challenged the effectiveness of corporatist compromises. On the one hand, the weakening of center-right parties has deprived trade unions and social democrats from their traditional partners with whom 
corporatist compromises could be struck in parliament (Interview 21). On the other hand, faced with fierce competition on their right, center-right parties have tended to adopt a more right-wing stance on welfare reform and align with the SVP. Even if concertation has still been a major way for the government to elaborate welfare reforms, parliament has often taken the lead and has been much less prone to sign on government proposals based on the consultation of social partners. In this context, incentives for the government to achieve corporatist compromises as such have been lower, since it became less likely that those compromises would be left untouched by a cohesive majority of right-wing parties in this domain. Corporatist procedures were still conducted because of the veto power given to trade unions, but few left-right compromises could be found between political parties (Interviews 19, 13). Corporatist compromises have often been greatly challenged and modified in the parliamentary process because unlike in labor migration policy, right-wing parties have shown a united stance over retrenchment, thereby marginalizing corporatist solutions considered too moderate (Interviews 19, 21). This could notably be observed in the last reforms of unemployment insurance in 2002 and 2010, or the eleventh revision of basic pensions and the latest revision of occupational pensions in 2008, where partial compromises between social partners were substantially challenged in parliament by a right-wing majority imposing further retrenchment measures, and opposed by social democrats.

In these cases, trade unions challenged the decision in popular referendums, thereby showing the failure of corporatist concertation. They could not gather a majority of voters in the cases of unemployment reform but were able to block unilateral retrenchment in pension reform. Hence, in this domain, corporatist policymaking seems to be in substantial decline, which stands in sharp contrast with its strengthening in labor migration policy. However, even if the pattern is substantially different between the strongly Europeanized and the weakly Europeanized, in terms of causation, it is the configuration of party coalitions rather than Europeanization per se that explains differences in concertation. More precisely, the fragmentation of party coalitions over labor migration-and particularly divisions within the right-spurred the government to choose concertation as a way to rally support from trade unions and social democrats. By contrast, an ideologically cohesive right-wing policy bloc has reduced incentives to seek compromises with trade unions and social democrats, since corporatist compromises were likely to be challenged in parliament.

\section{Conclusion}

In this article, we have outlined the mechanisms whereby European integration, domestic party politics, and corporatist policy concertation interact in decision-making processes. The main conclusion that can be drawn 
from our analysis is that the domestic configuration of party politics matters more to explain the choice of governments for concertation than the extent of Europeanization across policy domains. Since there is no systematic difference in the extent of concertation between strongly and weakly Europeanized policies, our findings show that domestic concertation is more influenced by governments' domestic political calculations, as conditioned by their strength and internal cohesion, than by supranational pressures (Avdagic 2010; Mastenbroek and Kaeding 2006). As shown in Table 2, one cannot observe a systematic impact of Europeanization on corporatist policymaking either in the direction of becoming weaker, or in the direction of becoming stronger. No empirical evidence could be found for the idea that Europeanization systematically opens up domestic policymaking to organized interests (Hypothesis 2) or systematically leads to more unilateral strategies of policymaking on the part of governments (Hypothesis 1). Whereas existing theories predicted a rather mechanistic and uniform impact of European integration, our empirical analysis shows

TABLE 2

Dominant Governance Patterns

\begin{tabular}{|c|c|c|c|}
\hline Case & Europeanization & $\begin{array}{c}\text { Party } \\
\text { Configuration }\end{array}$ & $\begin{array}{c}\text { Dominant Mode of } \\
\text { Decision Making }\end{array}$ \\
\hline $\begin{array}{l}\text { Austria: Labour } \\
\text { Migration Policy } \\
\text { 1995-1999 }\end{array}$ & Strong & Grand coalition & $\begin{array}{l}\text { Corporatist } \\
\text { compromise }\end{array}$ \\
\hline $\begin{array}{l}\text { Austria: Labour } \\
\text { Migration Policy } \\
\text { 2000-2006 }\end{array}$ & Strong & $\begin{array}{l}\text { Right-wing } \\
\text { cohesive } \\
\text { majority }\end{array}$ & Consultation \\
\hline $\begin{array}{l}\text { Austria: Labour } \\
\text { Migration Policy } \\
\text { 2006-2008 }\end{array}$ & Strong & $\begin{array}{l}\text { Grand coalition, } \\
\text { ideologically } \\
\text { divided }\end{array}$ & Concertation \\
\hline $\begin{array}{l}\text { Austria: Welfare } \\
\text { Reforms 1980s-1999 }\end{array}$ & Weak & Grand coalition & $\begin{array}{l}\text { Corporatist } \\
\text { compromise }\end{array}$ \\
\hline $\begin{array}{l}\text { Austria: Welfare } \\
\text { Reforms 2000-2006 }\end{array}$ & Weak & $\begin{array}{l}\text { Right-wing } \\
\text { cohesive } \\
\text { majority }\end{array}$ & $\begin{array}{l}\text { Unilateral } \\
\text { policymaking }\end{array}$ \\
\hline $\begin{array}{l}\text { Austria: Welfare } \\
\text { Reforms 2006-2008 }\end{array}$ & Weak & $\begin{array}{l}\text { Grand coalition, } \\
\text { ideologically } \\
\text { divided }\end{array}$ & $\begin{array}{l}\text { Corporatist } \\
\text { compromise }\end{array}$ \\
\hline $\begin{array}{l}\text { Switzerland: Labour } \\
\text { Migration Policy } \\
\text { 1995- }\end{array}$ & Strong & $\begin{array}{l}\text { Grand coalition, } \\
\text { ideologically } \\
\text { divided }\end{array}$ & $\begin{array}{l}\text { Corporatist } \\
\text { compromise }\end{array}$ \\
\hline $\begin{array}{l}\text { Switzerland: } \\
\text { Welfare Reforms } \\
\text { 1980-mid-1990s }\end{array}$ & Weak & $\begin{array}{l}\text { Grand coalition, } \\
\text { consensual }\end{array}$ & $\begin{array}{l}\text { Corporatist } \\
\text { compromise }\end{array}$ \\
\hline $\begin{array}{l}\text { Switzerland: Welfare } \\
\text { Reforms mid-1990s- }\end{array}$ & Weak & $\begin{array}{l}\text { Right-wing } \\
\text { cohesive } \\
\text { majority }\end{array}$ & Concertation \\
\hline
\end{tabular}


that this relationship is much more complex: National governments retain substantial control over the shape of the policy procedures, with or without Europeanization.

In Austria, the extent and evolution of corporatist policymaking is similar in both policy domains and varies more according to the characteristics of parties in office, so that Europeanization cannot be considered to have an independent causal impact. In Switzerland, by contrast, this evolution is very different between the two policy sectors, corporatism being characterized by a steady decline in welfare policies, whereas it has undergone a strengthening in labor migration policy, where the "EU factor" is strong. However, this impact is conditional on specific party coalitions in the two policy domains under scrutiny. Europeanization played a role because the stance toward European integration was the main line of divide among right-wing parties (thereby spurring the centerright to rally the left), but analytically, it was this party divide and the importance of finding a compromise rather than the direct impact of Europeanization per se that must be considered as a cause of the corporatist strategy pursued by the government. ${ }^{2}$

In many ways, our findings support existing research focusing on party politics as the main influence on the choice of governments for corporatist concertation, as Hypothesis 3 is confirmed. Hence, all the instances of corporatist compromises coincide with a form of weakness in terms of low parliamentary support or of coordination problems between major parties within the ruling party coalition. Corporatist policymaking proves to be a strategy of consensus mobilization that governments resort to when they face coordination problems within ideologically divided ruling parties. Corporatist policymaking was especially extensive during periods of grand coalition in Austria (1986-2000 and 2006 onward) and in the case of the free movement of workers in Switzerland. In all these cases, corporatist strategies of policymaking allowed governments to overcome coordination problems among ruling parties and build a base of political support for policies. For instance, in the context of important ideological differences between the ÖVP and social democrats, the strong cooperation patterns between Austrian social partners allowed for the negotiation of compromises at the center of the political spectrum; they acted as "arbiters" between political parties. In Switzerland, corporatist concertation on labor market re-regulation and the provision of side payments to trade unions allowed for the building of a policy coalition between center-right and social democrats in a context where right-wing parties were divided, and where center-right parties needed the left to build a parliamentary majority. By contrast, weaker corporatism was observed during the rightwing coalition FPÖ/ÖVP in Austria (2000-2006) and the recent domestic welfare reforms in Switzerland, that is, cases where right-wing parties had a majority in parliament, and displayed a united and relatively cohesive front. In this configuration, they did not need to build extra-parliamentary support either with trade unions or with social democrats. 
Independent of Europeanization, the configuration of party coalitions can thus be considered as the main causal trigger of corporatist strategies of policymaking. Of course, our argument needs to be tested on a larger sample of cases, providing the possibility to gather detailed empirical information on policy processes. Our analysis has indeed shown the necessity to apply fine-grained process-tracing methods to identify the causal mechanisms at work regarding the impact of international and domestic factors on national governance patterns. It has also shown the necessity to bring back agency and choice in the study of corporatism, instead of viewing it simply as a functional or merely structural phenomenon. Finally, it has shown the necessity to "bring governments back in" to the field of comparative political economy, where the focus has essentially been placed on employers in recent years.

\section{Acknowledgments}

Earlier versions of this article were presented at the ECPR joint sessions of workshops, Lisbon, April 2009, and at the Amsterdam IPE seminar, March 2010. For helpful comments and suggestions we would like to thank Barbara Vis, Johannes Lindvall, Brian Burgoon, Daniel Mügge, Mihai Varga, Annette Fryberg, Daniel Clegg, Pepper Culpepper, Alyson Price, the anonymous reviewers, and Robert H. Cox. Financial and logistic support by the Swiss National Science Foundation (NCCR Democracy) and the Max Weber Program of the European University Institute are gratefully acknowledged. The usual disclaimer applies.

\section{Notes}

1. Interview partners were representatives of the peak associations of trade unions and employers, government officials, and in a few cases, members of political parties or nongovernmental organizations. In total, 21 interviews were conducted (in the local language) between March 2007 and October 2008. Usually, the heads of labor market policy departments were the privileged interlocutors on the government side, and members of the executive secretariat on the side of employers and trade unions or, if unavailable, technical collaborators. All interviews but one were recorded and transcribed.

2. Previous research on other Europeanized cases pointed out a weakening effect of Europeanization on domestic concertation (Mach, Häusermann, and Papadopoulos 2003) but did not consider domestic patterns of party cleavages as a possible explanatory factor.

\section{References}

Ahlquist, John S. 2010. "Policy by Contract: Electoral Cycles, Parties and Social Pacts, 1974-2000." Journal of Politics 72 (2): 572-587.

Anthonsen, Mette, and Johannes Lindvall. 2009. "Party Competition and the Resilience of Corporatism." Government and Opposition 44 (2): 167-187. 
Avdagic, Sabina. 2010. "When Are Concerted Reforms Feasible? Explaining the Emergence of Social Pacts in Western Europe." Comparative Political Studies 43 (5): 628-657.

Avdagic, Sabina, Martin Rhodes, and Jelle Visser. 2011. Social Pacts in Europe: Emergence, Evolution, and Institutionalization. Oxford: Oxford University Press.

Baccaro, Lucio. 2003. "What Is Alive and What Is Dead in the Theory of Corporatism." British Journal of Industrial Relations 41 (4): 683-706.

- 2009. Similar Structures, Different Outcomes: The Surprising Resilience of Corporatist Policy-Making in Europe. Mimeo, University of Geneva.

Baccaro, Lucio, and Marco Simoni. 2008. "Policy Concertation in Europe. Understanding Government Choice." Comparative Political Studies 41 (10): 13231348 .

Bauböck, Rainer, and Bernhard Perchinig. 2006. Migrations-Und Integrationspolitik in Österreich. Bregenz: Okay-line Vorarlberg.

Bauböck, Rainer, and Hannes Wimmer. 1988. "Social Partnership and 'Foreigners Policy': On Special Features of Austria's Guest-Worker System." European Journal of Political Research 16 (6): 659-681.

Bundesarbeitskammer Österreich. 2004. "Antwort Auf Entwurf Eines Bundesgesetzes, mit dem das Ausländerbeschäftigungsgesetz und das Arbeitslosenversicherungsgesetz Geändert Werden (EU-ErweiterungsAnpassungsgesetz)."

Cattacin, Sandro. 1987. Neokorporatismus in der Schweiz: Die Fremdarbeiterpolitik. Zürich: Forschungsstelle für Politische Wissenschaft.

Conseil Fédéral. 2004a. "Message Concernant La Loi Fédérale Révisant Les Mesures d'Accompagnement à La Libre Circulation des Personnes."

— 2004b. "Message Portant Approbation Du Protocole à L'Accord Entre la Suisse et la Ce Sur La Libre Circulation des Personnes (04.066)."

Crepaz, Markus. 1994. "From Semisovereignty to Sovereignty. The Decline of Corporatism and Rise of Parliament in Austria." Comparative Politics 27 (1): 45-65.

Crouch, Colin. 1986. "Sharing Public Space: States and Organized Interests in Western Europe." In States in History, ed. J. Hall. Oxford: Blackwell.

Der Standard. 2000. "Bartenstein: Arbeitsmarktpolitik Muss Standortpolitik Werden." 09.02.2000, 22.

— 2009. "Interview Mit Emmerich Tálos: 'Sozialpartnerschaft Ist Eliteherrschaft'." January 16, 2009.

Ebbinghaus, Bernhard. 2010. "Reforming Bismarckian Corporatism: The Changing Role of Social Partnership in Continental Europe." In A Long Goodbye to Bismarck? The Politics of Welfare Reform in Continental Europe, ed. Bruno Palier. Amsterdam: Amsterdam University Press.

EIRO. 2003. "Thematic Feature-Social Partner Involvement in the 2003 Nap in Austria." http://www.eurofound.europa.eu/eiro/2003/10/tfeature/ at0310203t.htm.

—. 2004. "Controversy over Quota for Foreign Seasonal Workers." European Industrial Relations Observatory Online 2004 (3).

Fajertag, Giuseppe, and Philippe Pochet. 2000. Social Pacts in Europe: New Dynamics. Brussels: European Trade Union Institute.

Falkner, Gerda. 2000. "How Pervasive Are Euro-Politics? Effects of EU Membership on a New Member State." Journal of Common Market Studies 38 (2): 223-250.

Falkner, Gerda, and Simone Leiber. 2004. "Europeanization of Social Partnership in Smaller European Democracies?" European Journal of Industrial Relations 10 (3): 245-266.

Fischer, Alex, Sarah Nicolet, and Pascal Sciarini. 2002. "Europeanisation of Non-EU Countries: The Case of Swiss Immigration Policy Towards the EU." West European Politics 25 (4): 143-170. 
George, Alexander L., and Andrew Bennett. 2005. Case Studies and Theory Development in the Social Sciences. Cambridge, MA: MIT Press.

Grande, Edgar. 1996. "The State and Interest Groups in a Framework of MultiLevel Decision-Making: The Case of the European Union." Journal of European Public Policy 3 (3): 318-338.

Hamann, Kerstin, and John Kelly. 2007. "Party Politics and the Reemergence of Social Pacts in Western Europe." Comparative Political Studies 40 (8): 971-994.

- 2010. Parties, Elections, and Policy Reforms in Western Europe. Voting for Social Pacts. London: Routledge.

Hancke, Bob, and Martin Rhodes. 2005. "EMU and Labor Market Institutions in Europe: The Rise and Fall of National Social Pacts." Work and Occupations 32 (2): 196-228.

Häusermann, Silja, Andre Mach, and Ioannis Papadopoulos. 2004. "Social Policy Making under Strain in Switzerland." Swiss Political Science Review 10 (2): 3359.

Haverland, Markus. 2006. "Does the EU Cause Domestic Developments? Improving Case Selection in Europeanisation Research." West European Politics 29 (1): 134-146.

Heinisch, Reinhardt. 2000. "Coping with Economic Integration: Corporatist Strategies in Germany and Austria in the 1990s." West European Politics 23 (3): 67-96.

Heschl, Franz. 2008. "Europäische Integration und Arbeitsmigration nach Österreich Zwischen Arbeitnehmer-Und Arbeitgeberinteressen." Wirtschaft und Gesellschaft 2008 (2): 159-184.

Hooghe, Liesbeth, and Gary Marks. 2001. "Types of Multi-Level Governance." European Integration Online Papers 2001 (11).

Höpner, Martin, and Armin Schäfer. 2008. "Grundzüge Einer Politökonomischen Perspektive Auf Die Europäische Integration." In Die Politische Ökonomie der Europäischen Integration, ed. M. Höpner and A. Schäfer. Frankfurt am Main: Campus.

Katzenstein, Peter J. 1984. Corporatism and Change : Austria, Switzerland, and the Politics of Industry. Ithaca, NY: Cornell University Press.

Kriesi, Hanspeter. 1980. Entscheidungsstrukturen und Entscheidungsprozesse in der Schweizer Politik. Frankfurt: Campus.

Kriesi, Hanspeter, and Alexander H. Trechsel. 2008. The Politics of Switzerland: Continuity and Change in a Consensus Democracy. Cambridge, UK: Cambridge University Press.

Lehmbruch, Gerhard. 1977. "Liberal Corporatism and Party Government." Comparative Political Studies 10 (1): 91-126.

Lehmbruch, Gerhard, and Philippe C. Schmitter. 1982. Patterns of Corporatist Policy-Making. London: Sage.

Levi-Faur, David. 2004. "On the Net Impact of Europeanization. The EU's Telecoms and Electricity Regimes between the Global and the National." Comparative Political Studies 37 (1): 3-29.

Mach, Andre, Silja Häusermann, and Ioannis Papadopoulos. 2003. "Economic Regulatory Reforms in Switzerland: Adjustment without European Integration, or How Rigidities Become Flexible." Journal of European Public Policy 10 (2): 301318.

Mastenbroek, Ellen, and Michael Kaeding. 2006. "Europeanization Beyond the Goodness of Fit: Domestic Politics in the Forefront." Comparative European Politics 4 (4): 331-354.

Moravcsik, Andrew. 1994. "Why the European Community Strengthens the State: Domestic Politics and International Cooperation." CES Working Papers 52.

Neidhart, Leonard. 1970. Plebiszit und Pluraritäre Demokratie. Bern: Franke. 
Obinger, Herbert. 2008. "Sozialpolitische Bilanz Der Großen Koalition in Österreich." Paper presented at the Drei-Ländertagung of the DVPW, SVPW, ÖGPW 2008 in Osnabrück, Germany.

Obinger, Herbert, and Emmerich Talos. 2006. Sozialstaat Österreich Zwischen Kontinuität Und Umbau. Eine Bilanz Der ÖVP/FPÖ/BZÖ Koalition. Wiesbaden: VS Verlag für Sozialwissenschaften.

—. 2010. "Janus-Faced Developments in a Prototypical Bismarckian Welfare State. Welfare Reforms in Austria since the 1970s." In A Long Good-Bye to Bismarck? The Politics of Welfare Reform in Continental Europe, ed. B. Palier. Amsterdam: Amsterdam University Press.

Osterreichisches Parlament. 2004. 414 D.B. (Xxii. Gp) Eu-ErweiterungsAnpassungsgesetz. Materialien. Wien: Nationalrat.

Pelinka, Anton. 2008. "Gesetzgebung im Politischen System Österreichs." In Gesetzgebung in Den Staaten Der Europäischen Union, ed. W. Ismayr. Wiesbaden: VS Verlag für Sozialwissenschaften.

Radaelli, Claudio M. 2003. "The Europeanization of Public Policy." In The Politics of Europeanization, ed. K. Featherstone and C. M. Radaelli. Oxford: Oxford University Press.

Risse, Thomas, and Tanja A. Börzel. 2003. "Conceptualizing the Domestic Impact of Europe." In The Politics of Europeanization, ed. K. Featherstone and C. M. Radaelli. Oxford: Oxford University Press.

Sartori, Giovanni. 1976. Parties and Party Systems: A Framework for Analysis. Cambridge, UK: Cambridge University Press.

Schmidt, Vivien. 2006. "Procedural Democracy in the EU: The Europeanization of National and Sectoral Policy-Making Processes." Journal of European Public Policy 13 (5): 670-691.

Schmitter, Philippe C. 2003. "Democracy in Europe and Europe's Democratization." Journal of Democracy 14 (4): 71-85.

Schmitter, Philippe C., and Juergen Grote. 1997. The Corporatist Sisyphus: Past, Present and Future. Florence: European University Institute Working Paper Series $97 / 4$.

Stenographisches Protokoll. 2004. "55. Sitzung Des Nationalrates Der Republik Österreich. XXII. Gesetzgebungsperiode Mittwoch, 24. März 2004."

Talos, Emmerich, and Bernhard Kittel. 2001. Gesetzgebung in Österreich. Netzwerke, Akteure und Interaktionen in Politischen Entscheidungsprozessen. Wien: Facultas.

Traxler, Franz, Sabine Blaschke, and Bernhard Kittel. 2001. National Labour Relations in Internationalized Markets: A Comparative Study of Institutions, Change, and Performance. Oxford: Oxford University Press.

Tsebelis, George. 1999. "Veto Players and Law Production in Parliamentary Democracies: An Empirical Analysis." American Political Science Review 93 (3): 591-608.

Tumpel, Herbert. 2004. "Baustelle Europa-Eine Bilanz Aus Arbeitnehmersicht." <http:/ / www.ena.lu/herbert_tumpel_baustelle_europa_bilanz_

arbeitnehmersicht_2004-030006862.html>. (accessed April 18, 2012).

Visser, Jelle, and Anton Hemerijck. 1997. A Dutch Miracle. Job Growth, Welfare Reform and Corporatism in the Netherlands. Amsterdam: Amsterdam University Press.

\section{List of Interviews}

1. Section Chief, Labour Force, Austrian Public Employment Service AMS, September 23, 2008, Vienna. 
2. Section Chief, International Affairs, Austrian Confederation of Trade Unions ÖGB, September 30, 2008, Vienna.

3. Section Chief, Labour Market Policy, Austrian Chamber of Labour, October 2, 2008, Vienna.

4. Collaborator Section EU and International Affairs, Austrian Chamber of Labour, October 2, 2008, Vienna.

5. Social Affairs Advisors, Green Party Austria, October 3, 2008, Vienna.

6. Head of Section, Labour Market Policy, Austrian Federal Ministry for Economics and Labour, October 7, 2008, Vienna.

7. Collaborator Section Social Policy, Austrian Economic Chamber, October 8, 2008, Vienna.

8. International and EU labour market law specialist, Austrian Federal Ministry of Economics and Labour, October 9, 2008, Vienna.

9. Collaborator Section Swiss Labour Market Policy, Austrian Chamber of Labour, October 13, 2008, Vienna.

10. MP Council of States, Social Democratic Party, March 1, 2007, Geneva.

11. Former Head of Sector Labor Relations, State Secretariat for Economic Affairs, March 9, 2007, Neuchatel.

12. President of the Swiss Trade Union Federation, March 20, 2007, Bern.

13. President of Special Commission "Flanking Measures" of National Council, Social Democratic Party, March 20, 2007, Bern.

14. Vice Director of the Swiss Union of Crafts and SMEs, March 26, 2007, Bern.

15. Former Federal Councillor and Head of Federal Department of the Economy, April 2, 2007, Fribourg.

16. Central Secretary, Swiss Federation of Trade Unions, April 3, 2007, Bern.

17. Member of Direction, Swiss Employers' Union, May 11, 2007, Bern.

18. MP, Swiss Social Democratic Party, June 19, 2007, Bern.

19. Former Central Secretary of the Swiss Trade Union Federation, December 11, 2007, Bern.

20. Deputy Head of Project Unemployment Insurance Reform, Swiss State Secretariat for Economic Affairs, March 11, 2008, Bern.

21. MP, Swiss Social Democratic Party, May 6, 2008, Bern. 